\title{
Increasing rice productivity and profitability through irrigation water management and bio- fertilizer in West Nusa Tenggara
}

\author{
Risqa Nurkhaida $^{1 *}$, Adang Hamdani ${ }^{1}$, Ahmad Suriadi ${ }^{2}$, and Nani Heryani ${ }^{1}$ \\ ${ }^{1}$ Indonesian Agroclimate and Hydrology Research Institute, Bogor, Indonesia \\ ${ }^{2}$ Assessment Institute for Agricultural Technology West Nusa Tenggara, Indonesia
}

\begin{abstract}
Limited water resources in dry land area become a crucial factor in crop production. The research aims were to determine the effect of irrigation network arrangement and application of biofertilizer on rice productivity, and the feasibility of developing irrigation infrastructure to increase farmers' income. The study was conducted in Mbawa Village, Donggo District, Bima Regency, West Nusa Tenggara. In addition to repairing irrigation network, five different cultivation practices were applied, i.e. (1) farmer's practice with integrated crop management, (2) farmer's practices added with biofertilizers, (3) Recommended dosage fertilization, (4) Recommended dosage fertilization added with biofertilizer, and (5) farmer's practices as control. Farming analysis was carried out by calculating farm cash flow, while the feasibility of developing irrigation infrastructure was carried out by calculating IRR, NPV and Net BCR. The results showed that application of biofertilizer increased the production of straw and rice yields. Farming and financial analysis of irrigation infrastructure showed that irrigation infrastructure investment was feasible to develop with a relatively fast return on capital and can increase farmers' income. Through improved irrigation infrastructure, the use of biological fertilizers, and proper irrigation water management can increase rice productivity and farmers' income.
\end{abstract}

\section{Introduction}

Management of water resources is one of the important aspects in increasing the cropping index, especially in dry land. Currently, total dry land in Indonesia was 144.47 million ha and around 91.53 million ha $(63.35 \%)$ was land suitable for agriculture sector, and $36.67 \%$ suitable for food crops [1]. Based on the climate classification, the dry land can be grouped into dry land with a wet climate for about 133.7 million ha and dry land with a semi-arid climate for about 10.8 million ha [2]. Almost half of the dry land with a semi-arid climate was located in the Provinces of West Nusa Tenggara (NTB) and East Nusa Tenggara (NTT) $(48.2 \%)$, and the rest spread in the east area of Indonesia [3].

Bima Regency, NTB Province is part of a dry land with semi-arid climate where the water supply for agriculture is scarce, especially during the dry season of planting. Lack of

* Corresponding author: risqanurkhaida@gmail.com 
water availability for agriculture causes crop productivity will not be optimal and the average cropping index (IP) was 1 crop per year (IP 100). Water management and the use of drought tolerant varieties, as well as land management through increasing soil fertility could be considered as important factors to increase land productivity and profitability. Water-saving irrigation or supplying crop water requirement can increase the area of irrigation services so as to increase the cropping index and agricultural production [4]. In general, water supply at tertiary level usually was not sufficient to irrigate rice fields. The high water loss on delivering water to the rice fields was generally triggered by the bad condition of the damaged channel. One of the efforts to reduce water loss and increase the discharge in the rice fields is lining the waterways or channel. The loss of water in the canal is generally caused by infiltration, evaporation and water leaks or seepage which caused decrease irrigation efficiency. The decrease in irrigation efficiency in the distribution of semi-technical irrigation networks was reach to $47.61 \%$ that was lower than the ideal value of irrigation efficiency of $68.8 \%$ [5].

In addition to adequate water availability for plants cultivation, increasing soil fertility through fertilization will result in optimal crop production. Soil fertility in dry land and semiarid climates was generally low due to shallow soil solum and rocky land, especially on sloping land. However the use of biological fertilizers in flat rice fields can increase land and crop productivity. Biological fertilizers are useful for increasing the growth and productivity of food crops (rice/soybeans), horticulture (chilies/vegetables), and plantations (sugarcane) $[6,7,8]$. The application of biofertilizer Agrimeth in lowland rice and field rice farming can save the use of inorganic fertilizers N, P, and K by $50 \%$ and increase the income of rice farmers [6]. Moreover, the use of biofertilizer can also reduce the use of N, P, and $\mathrm{K}$ fertilizers by up to $50 \%$ in horticultural crops [7]. The use of biofertilizer was also able to increase rice yield by 1.4 tons/ha or an increase of $20.77 \%$ and was able to reduce the use of inorganic fertilizers by up to $25 \%$ [8]. Combination of inorganic fertilizer and biofertilizer increase the height, bar diameters, bar weight, and root weight of sugarcane cultivation [9].

Irrigation networks on paddy fields in Mbawa village, Donggo sub-district, Bima district, NTB are generally in poorly maintained condition. Water distribution was not optimal due to damage in some parts of channel causing an increase water loss during distribution. Furthermore, the use of biological fertilizers that increase plant productivity has been done somewhere, but has not been used at the farmer level for various non-technical reasons, such as unavailable in market during rice growing season and factors of farmers' habits [3]. This study aims were to understand the effect of biofertilizers and irrigation network infrastructure arrangement on rice productivity and profitability.

\section{Materials and methods}

\subsection{Materials}

The research was conducted from January to June 2019 in Mbawa Village, Donggo District, Bima Regency. The materials used in this study were: rice seeds (Situ Bagendit variety), inorganic fertilizers (phonska and urea), biofertilizer, insecticides, pesticides, and building materials (river stone, sand, cement, etc). 


\subsection{Methods}

\subsubsection{Arrangement of Irrigation Network}

The arrangement of the irrigation network was carried out on the rice farm for length of 900 $\mathrm{m}$. There has been made a new irrigation channel of $600 \mathrm{~m}$ and repaired (lining) of existing irrigation channels of $300 \mathrm{~m}$. Irrigation network was improved by repairing on damaged part of channel to normally serve water delivery and can suppress water loss due to seepage or infiltration into the soil.

\subsubsection{Experimental design}

There were 5 treatment combinations of the experiment applied that was layout as a randomized block design with 4 replications. The rice field used in this experiment was 50 ha, involving 40 farmers as cooperator. Those treatments were:

1. Farmer practice (FP): Fertilizing according to the farmer's method, namely using a dose of $300 \mathrm{~kg}$ urea/ha and phonska $50 \mathrm{~kg} / \mathrm{ha}$, following the technical guidelines for integrated crop management (ICM) for upland rice cultivation (PHy0),

2. FP + biofertilizer (PHy1),

3. Recommended dose of fertilization (RF) (250 kg urea/ha and phonska $200 \mathrm{~kg} / \mathrm{ha})$ applied 3 times (AHy0),

4. RF+ biofertilizer (AHy1),

5. Fertilizing according to the farmer's method, namely using a dose of $300 \mathrm{~kg}$ urea/ha and phonska $50-100 \mathrm{~kg} / \mathrm{ha}$ with their own farmer's cultivation method (non-cooperator farmers) as control (PM).

Parameters measured in this experiment includes yield on dry-harvested rice (DHR) and drymilled rice (DMG) and the straw. Data was collected by fields' observations and analyzed statistically using analysis of variance (ANOVA) using Minitab 16.

\subsubsection{Financial-economic analysis of farming system}

Farming feasibility analysis was conducted to determine the feasibility of the farming business developed from a financial aspect. The indicators to determine the feasibility of a project to be disseminated can be through the calculation of the Net Benefit Cost Ratio (Net BCR), Net Present Value (NPV), Internal Rate of Return (IRR) [10]. Net Benefit Cost Ratio (Net BCR) is the ratio between the number of positive NPVs and the number of negative NPVs or the ratio between the benefits and financing of a project to be implemented and is calculated using the formula as follows [11]:

$$
B C R=\frac{B e n e f i t}{\text { Cost }}
$$

The indicators of the BCR value as follows [12]:

$\mathrm{BCR}>1$ indicating the farming is profitable,

$\mathrm{BCR}<1$ indicating the farming is unprofitable or unfeasible,

$\mathrm{BCR}=1$ indicating the value of farming cost and profit was equal.

Net Present Value (NPV) is the present value of the difference between benefits and costs at a certain discount rate. 
NPV describes profits and feasible if it has a positive value. If NPV $=0$, then the investment made is neither profitable nor loss (marginal or mediocre), indicating that the investment can be implemented or not. If the NPV $<0$ then the business is detrimental so it is better not to do it. Internal Rate of Return (IRR) is a project's ability to repay loan interest from internal financial institutions that finance the project/business and calculated using the formula as follows [13]:

$$
I R R=i_{1} \frac{N P V_{1}}{N P V_{1}-N P V_{2}} x\left(i_{1}-i_{2}\right)
$$

Where, $i_{1}$ is discount rate at $\mathrm{NPV}_{1}$ and $\mathrm{i}_{2}$ is discount rate at $\mathrm{NPV}_{2}$.

Data was collected by measurable observations of cooperator farmers and interviews with non-cooperator farmer. The median test for each variable (expenditure, income and benefit) of rice farming system for each farming group was calculated by Two-Sample T-test using Minitab 16.

\section{Results and discussions}

\subsection{Characteristics of Bima Regency}

Bima Regency, which is part of the Province of West Nusa Tenggara (NTB), is laid at the eastern part of the Province of West Nusa Tenggara (NTB). The total area of Bima Regency was $4,374.65 \mathrm{~km}^{2}$, consisting of $315.96 \mathrm{~km}^{2}$ or $7.22 \%$ of irrigated rice fields and $4,058.69$ $\mathrm{km}^{2}(92.78 \%$ ) of non-rice fields (dryland) [14]. One of the sub-districts in Bima Regency is Donggo District which has an area of 123.83 ha and was divided into 9 villages, where the largest village is Mbawa Village and the smallest is Doridungga Village. The Donggo subdistrict is bordered by the Soromandi sub-district in the north and east, Madapangga and Bolo sub-districts in the south, and Dompu district in the west.

The area of irrigated rice field in Donggo District was 1,376 ha. The harvested area for food crops is 4,031 ha, the harvested area for vegetables is 22 ha, and the harvested area for fruits is $77 \mathrm{ha}$, and the harvested area for plantation crops is $230 \mathrm{ha}$. In particular, at the study location in Mbawa Village, the area of rice fields reaches 237 hectares and dry fields/fields reach 741 hectares, as well as state forest which is partly used by the community for agriculture through the PHBM program (Community Forest Management) covering an area of 1,348 hectares [15]. The research location is in Sangari Village, Mbawa Village, Donggo District, Bima Regency, located at the top of a hill with a hilly topography. The slope was slightly steep and contains $25-35 \%$ rock on the ground surface. The area of land that has the potential to increase cropping index (IP) was around 30 ha if a water source is available. With river water discharge of around $1.5-2.5 \mathrm{l} / \mathrm{second}$, there is a potential for increasing IP through maize cultivation at planting season of 3 . In addition, there are potential rice field lands of approximately 50 ha to improve the IP located at the bottom of the hill. The land was irrigated paddy field and its irrigation comes from a reservoir built by the government. The discharge at the top point of the land was about $8 \mathrm{l} / \mathrm{second}$. The land was used for cultivation of several crops such as soybeans, corn, peanuts, and watermelon [16].

\subsection{Irrigation network design}

The irrigation system in dry and rocky land developed in Mbawa Village, Donggo District, Bima regency comes from a river that was channeled through a channel reservoir built since 
2013. However, the condition of the channel in some parts was damaged and other parts the channel was built using soil. Thus, the channel needs to improve and rebuild.

There has been made a new irrigation channel of $600 \mathrm{~m}$ and repaired (lining) of existing irrigation channels of $300 \mathrm{~m}$ in order to increase land productivity through increasing the cropping index from 1 time to 2 plantings for 50 ha of rice dryland. Channel lining served to reduce water loss, prevent scouring and erosion, prevents the development of aquatic plants, and reduces maintenance costs. Irrigation investment through this lining becomes very important and strategic effort in the context of providing water for agriculture. The decline in the condition and function of the channel lining generally results in leakage and landslide of the channel embankment. Water loss in the channel other than leakage was also caused by the accumulation of garbage in the channel, and the growth of wild plants along the channel [17].

Disruption or damage to one part of irrigation building will affect the performance of water delivering system, resulting decreased in efficiency and effectiveness of irrigation. If this condition is allowed to continue and is not immediately addressed, it will have an impact on the expected decline in agricultural production, and have negative implications for farmers' income and impacted on social and economic conditions around the location [18].
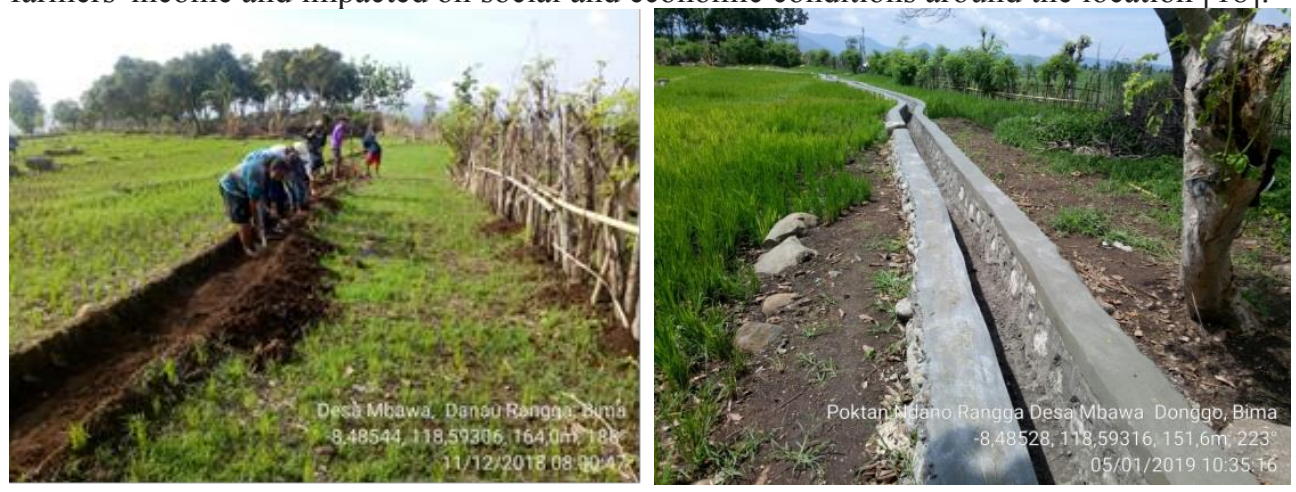

Fig. 1. Channel condition before (A) and after (B) rebuilt

\subsection{The effect of biofertilizer on rice cultivation}

Rice cultivation in dryland was carried out on a 50 ha, involving 2 farmer groups, namely the Ndano Rangga 1 and Ndano Rangga 2 farmer groups. Land preparation was carried out without tillage by clearing the land and spraying the herbicides gramoxone and lindomin. After the soil moisture was high enough with minimum of $50 \mathrm{~mm}$ of rainfall within 20 days, the farmers plant rice by dibbling at spacing of $20 \times 20 \mathrm{~cm}$ without planting lines. Selective herbicides were sprayed if weeds had grown.

In general, the application of biofertilizer at various combinations of fertilizer treatments did not give significantly different rice yields for the dry-harvested rice (DHR However, in this study there was a tendency to increase the yield of dry-milled rice (DMR) with the application of biofertilizers. Several research results show that the use of biofertilizers can increase rice productivity $[19,20]$. The use of inorganic fertilizers and biological fertilizers not only increased rice yields but it also reduced the use of inorganic fertilizers $[21,22]$. The results of other studies show that the right combination of biological fertilizers and inorganic fertilizers can increase rice yields [23,24].

Yield of rice at DHR and at DMR at various treatments is presented at Figure 2. The results of experiment in the Figure 2 shows that the highest yield of rice was obtained at treatment AHy1 (recommended doze of fertilization with biofertilizer) in both grain moisture conditions of DMR and DHR (5.6 ton/ha), although this was not significantly different with 
treatment PHy1 (farmer practice with biofertilizer). The lowest rice yield was obtained from PM (non-cooperator farmers method/control) treatment although this was not significantly different with treatment PHy0 (farmer practice) and AHy0 (recommended doze of fertilization without biofertilizer). This result indicated that biofertilizer was able to increase rice yield on average of 0.7 ton/ha on DHR based or 0.9 ton/ha on DMR based compared to PM treatment. Rustiati and Widyantoro state that the application of agrimeth biofertilizer can increase up to $21,72 \%$ for Inpago 8 varieties rice yield [25].

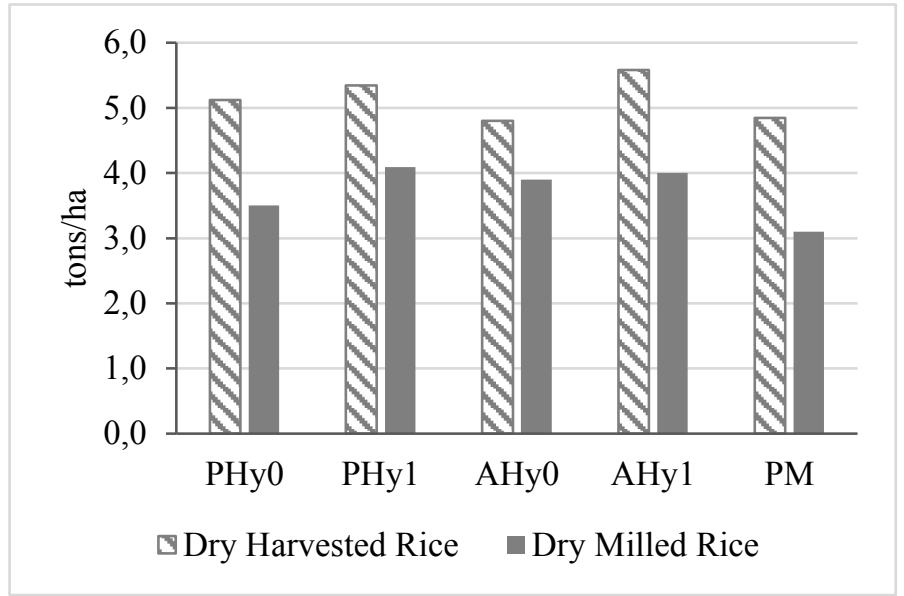

Fig. 2. Rice yield on DHR and DMR based on various treatment of fertilizer.

A two way anova test was conducted to determine the effect of various types of fertilization on rice and straw productivity. The result of analysis showed that the various types of fertilization is not have significant effect on rice productivity with P-value of 0,143 which was greater than the value of $\alpha=0.05$. However, when further test (Tukey Simultaneous Tests) was carried out, recommended dose of fertilization with biofertilizer (agrimeth) was proven to increase rice yields compared to other fertilization methods showed in Figure 3. We can see the difference of means of each treatment, value of AHy1 is positive compared to AHyo. PHy0, PHy1, and PM are negative compared to AHy1, which means that recommended dose of fertilization with biofertilizer was better than fertilization with other methods.

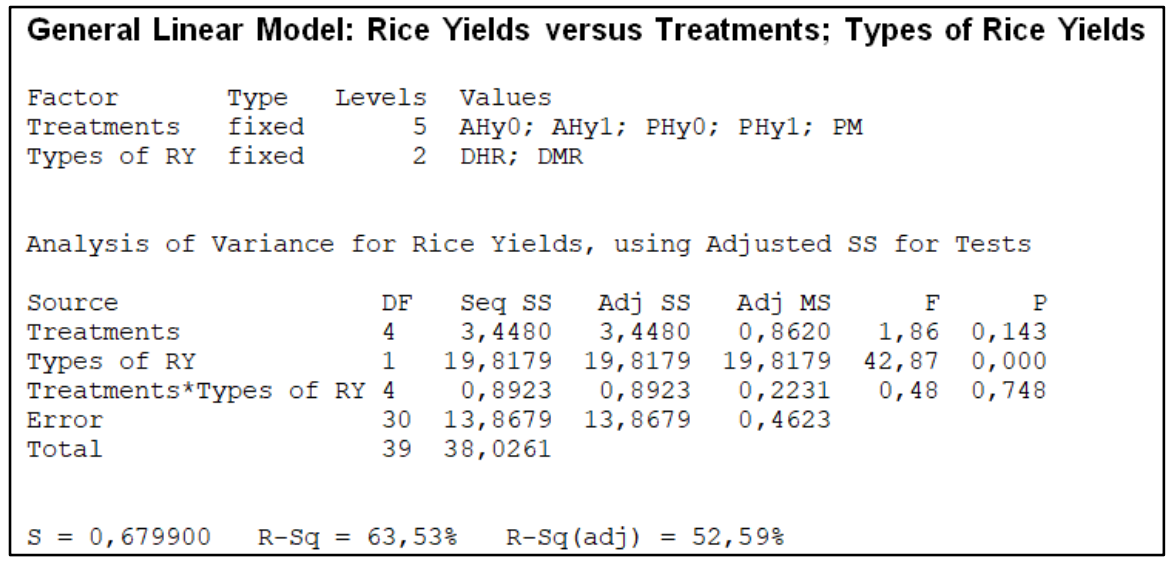

Fig. 3. ANNOVA Test Result for Rice Yields 


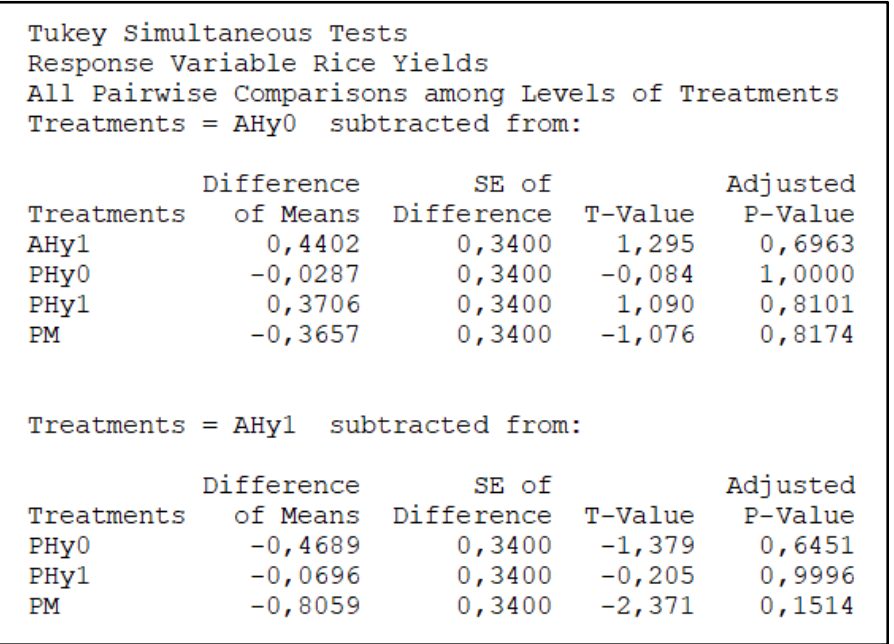

Fig. 4. Anova further test result using Tukey Simultaneous Test

Rice straw production at various fertilization treatments is shown on Figure 4. There was a tendency that rice straw was higher in the (AHy1) compared to other fertilization methods. The yield of wet straw in the AHyl treatment reached the highest yield of 32.8 tons/ha and the lowest was in the PM treatment, which was 24.0 tons/ha. The production of dry straw in the AHy1 treatment reached 10.3 tons/ha and the lowest was in the farmer method (PM) at 7.0 tons/ha.

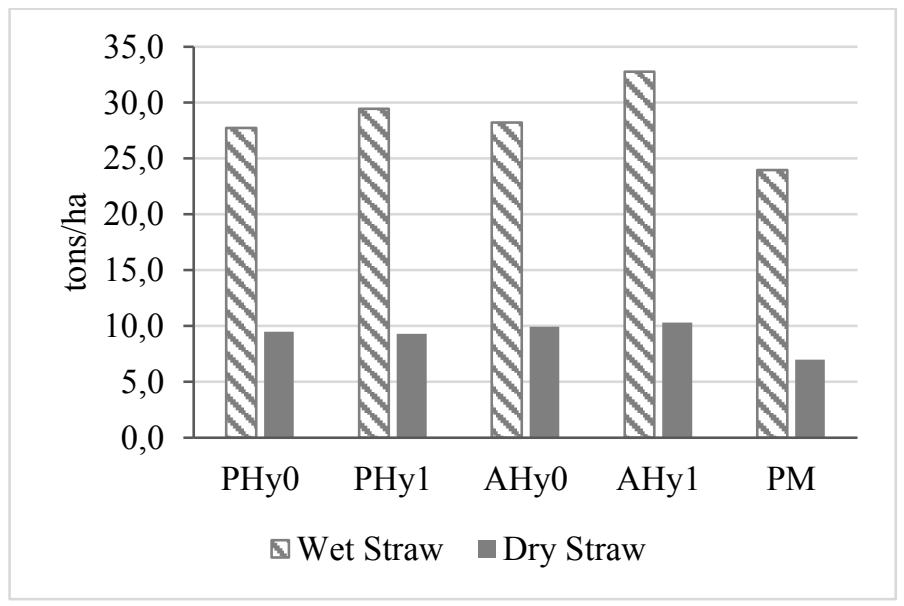

Fig. 5. Wet and dry straw yields at various fertilizer treatments

The result of two way anova test showed that the various types of fertilization is have effect on straw productivity with P-value of 0,000 which was lesser than the value of $\alpha=$ 0.05 . Recommended dose of fertilization with biofertilizer was proven to increase straw productivity compared to other fertilization methods. 


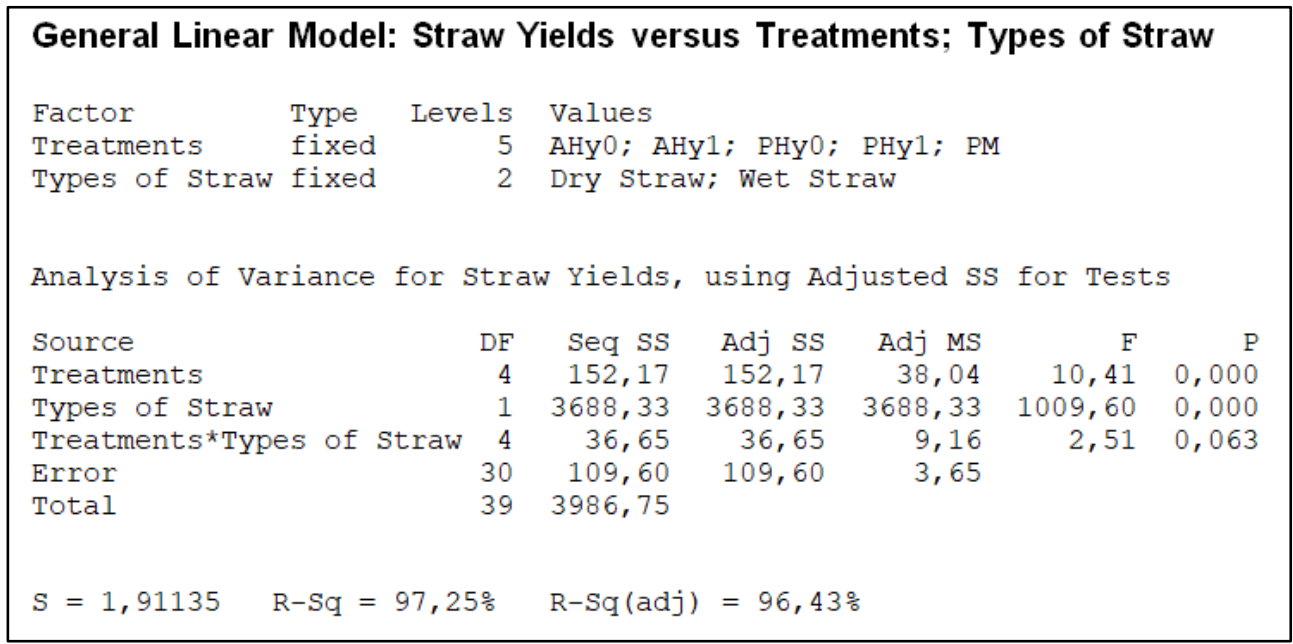

Fig. 6. ANNOVA Test Result for Straw Yields

\subsection{Financial analysis of farming system and irrigation infrastructure}

\subsubsection{Financial-economic analysis of farming system}

Financial analysis of rice farming system after irrigation infrastructure has been improved is presented in Table 1. In general, BC ratio value that more than zero indicated farmers have gained the profit by using improved infrastructure. The average $\mathrm{BC}$ ratio value was obtained at 0.66 , meaning that one rupiah of capital used by farmers in their farming expenditure will provide benefits of 0.66 rupiah. The $\mathrm{BC}$ ratio was varies in the range of $0.08-1.61$. 
Table 1. Variation of cost and revenues of cooperator farmer

\begin{tabular}{|c|c|c|c|c|c|c|}
\hline No & Name & Land size & Cost & Revenue & Benefit & BCR \\
\hline 1 & Jaenab & 0.49 & $5,387,000$ & $8,928,000$ & $3,541,000$ & 0.66 \\
\hline 2 & Anwar, S. Pd & 0.50 & $3,920,000$ & $4,216,000$ & 296,000 & 0.08 \\
\hline 3 & Sukardin & 0.67 & $4,164,500$ & $8,400,000$ & $4,235,500$ & 1.02 \\
\hline 4 & H. Ismail & 0.37 & $3,771,000$ & $7,688,000$ & $3,917,000$ & 1.04 \\
\hline 5 & M. Umar & 0.45 & $4,754,500$ & $7,200,000$ & $2,445,500$ & 0.51 \\
\hline 6 & M. Umar Ishaka & 0.68 & $6,614,500$ & $7,200,000$ & 585,500 & 0.09 \\
\hline 7 & Ahmad & 0.30 & $4,856,500$ & $6,944,000$ & $2,087,500$ & 0.43 \\
\hline 8 & Kasmir & 0.25 & $3,140,000$ & $6,448,000$ & $3,308,000$ & 1.05 \\
\hline 9 & Hadijah Abbas & 0.58 & $6,512,500$ & $12,960,000$ & $6,447,500$ & 0.99 \\
\hline 10 & Nasrudin, S. Pds & 0.60 & $7,270,500$ & $12,648,000$ & $5,377,500$ & 0.74 \\
\hline 11 & Ibrahim Tayeb & 0.75 & $5,605,000$ & $7,440,000$ & $1,835,000$ & 0.33 \\
\hline 12 & Lutfi Manan & 0.72 & $6,752,500$ & $12,896,000$ & $6,143,500$ & 0.91 \\
\hline 13 & Sukirman & 0.24 & $2,686,000$ & $4,216,000$ & $1,530,000$ & 0.57 \\
\hline 14 & Suaeb, S. Pd & 1.05 & $11,370,000$ & $21,328,000$ & $9,958,000$ & 0.88 \\
\hline 15 & Syamsuddin & 0.47 & $4,808,000$ & $9,360,000$ & $4,552,000$ & 0.95 \\
\hline 16 & Kalisomn & 0.25 & $3,420,000$ & $5,208,000$ & $1,788,000$ & 0.52 \\
\hline 17 & Rahmah, S. Pd & 1.00 & $6,915,000$ & $10,500,000$ & $3,585,000$ & 0.52 \\
\hline 18 & M. Nur & 0.25 & $2,920,000$ & $4,760,000$ & $1,840,000$ & 0.63 \\
\hline 19 & Hadijah AR & 0.62 & $10,437,000$ & $17,608,000$ & $7,171,000$ & 0.69 \\
\hline 20 & Usman & 0.50 & $4,420,000$ & $7,936,000$ & $3,516,000$ & 0.80 \\
\hline 21 & M. Said & 1.00 & $8,555,000$ & $12,400,000$ & $3,845,000$ & 0.45 \\
\hline 22 & Supardi & 1.20 & $8,363,000$ & $16,800,000$ & $8,437,000$ & 1.01 \\
\hline 23 & Nasarudin & 0.30 & $5,170,000$ & $5,985,000$ & 815,000 & 0.16 \\
\hline 24 & H. Ismail & 0.60 & $5,170,000$ & $9,450,000$ & $4,280,000$ & 0.83 \\
\hline 25 & Amirudin & 0.40 & $3,629,000$ & $4,712,000$ & $1,083,000$ & 0.30 \\
\hline 26 & Syafrudinn & 0.35 & $5,300,000$ & $7,875,000$ & $2,575,000$ & 0.49 \\
\hline 27 & Anwar & 0.40 & $5,962,500$ & $8,100,000$ & $2,137,500$ & 0.36 \\
\hline 28 & Ibrahim & 0.35 & $4,705,000$ & $7,425,000$ & $2,720,000$ & 0.58 \\
\hline 29 & H. Sulaiman & 0.50 & $5,695,000$ & $9,900,000$ & $4,205,000$ & 0.74 \\
\hline 30 & Abdullah & 0.50 & $4,820,000$ & $7,200,000$ & $2,380,000$ & 0.49 \\
\hline 31 & Supriadin & 0.50 & $5,170,000$ & $7,200,000$ & $2,030,000$ & 0.39 \\
\hline 32 & Burhan & 0.43 & $3,410,000$ & $6,600,000$ & $3,190,000$ & 0.94 \\
\hline 33 & Abidin & 0.35 & $3,532,500$ & $4,750,000$ & $1,217,500$ & 0.34 \\
\hline 34 & Hamsidi & 0.25 & $2,260,500$ & $5,850,000$ & $3,589,500$ & 1.59 \\
\hline 35 & Ibrahim & 0.30 & $2,680,000$ & $5,850,000$ & $3,170,000$ & 1.18 \\
\hline 36 & H. Abdullah & 0.30 & $3,551,500$ & $5,200,000$ & $1,648,500$ & 0.46 \\
\hline 37 & H. Ismail & 0.80 & $6,595,000$ & $8,680,000$ & $2,085,000$ & 0.32 \\
\hline 38 & M. Hasan & 0.80 & $6,260,000$ & $9,207,000$ & $2,947,000$ & 0.47 \\
\hline 39 & H. Yusuf & 0.56 & $3,551,500$ & $9,272,000$ & $5,720,500$ & 1.61 \\
\hline \multirow[t]{3}{*}{40} & Abakar & 0.46 & $5,305,000$ & $7,800,000$ & $2,495,000$ & 0.47 \\
\hline & Total & 21.09 & $209,410,000$ & $344,140,000$ & $134,730,000$ & 26.59 \\
\hline & Average & 0.53 & $5,235,250$ & $8,603,500$ & $3,368,250$ & 0.66 \\
\hline
\end{tabular}

To find out changes in the scale of farming from the development of irrigation infrastructure, it is necessary to compare between farmers who are involved in the research (cooperative farmers) and farmers who are not involved in the research (non-cooperative) in the area. A total of 11 non-cooperativefarmers have been interviewed as shown in Table 2. It can be seen that the value of the BC Ratio of cooperative farmers (Table 1) was greater than that of non-cooperative farmers. Data obtained from non-cooperator farmer is the result of interviews so that data $b$ Through the improvement of irrigation infrastructure, the cooperative farmers are able to expand their irrigated land which impact on their rice 
productivity and income.It also caused by some of non-cooperative farmer are unable to do farming due to their land does not have water supply so that farmers' income were considered zero.

Table 2. Variation of cost and revenues of farmer non-cooperator

\begin{tabular}{|c|c|c|c|c|c|c|}
\hline No & Name & Land size & Cost & Revenue & Benefit & BCR \\
\hline 1 & Lutfi & 0.25 & $2,530,000$ & $2,976,000$ & 446,000 & 0.18 \\
\hline 2 & H. M. Saleh & 1.25 & $8,835,000$ & $12,648,000$ & $3,813,000$ & 0.43 \\
\hline 3 & M. Amin & 0.91 & $7,220,000$ & $19,680,000$ & $12,460,000$ & 1.73 \\
\hline 4 & M. Nur & 0.43 & $3,753,500$ & $7,056,000$ & $3,302,500$ & 0.88 \\
\hline 5 & NurIna & 0.25 & - & - & - & 0.00 \\
\hline 6 & Ahmad Kosimi & 0.40 & - & - & - & 0.00 \\
\hline 7 & Fuad & 0.38 & $3,998,000$ & $6,944,000$ & $2,946,000$ & 0.74 \\
\hline 8 & Cahyadin & 0.31 & $4,164,000$ & $6,240,000$ & $2,076,000$ & 0.50 \\
\hline 9 & H. Hasan Musa & 0.71 & $6,353,000$ & $15,103,200$ & $8,750,200$ & 1.38 \\
\hline 10 & Nurasia & 0.50 & - & - & - & 0.00 \\
\hline 11 & Mukmina & 1.20 & - & - & - & 0.00 \\
\hline & Total & 6.59 & $36,853,500$ & $70,647,200$ & $33,793,700$ & 5,84 \\
\hline & Average & 0.60 & $5,264,786$ & $10,092,457$ & $4,827,671$ & 0.53 \\
\hline
\end{tabular}

Furthermore, the median test for each variable was conducted in order see partially between expenditure, income and benefit of rice farming system for each farming group using Two-Sample T-test level 95\%. The result of analysis showed that the construction of irrigation infrastructure increased farmers' expenditure for their farming business with Pvalue of 0.086 which was greater than the value of $\alpha=0.05$. In term of revenue, it indicated that the construction of irrigation infrastructure increases farmers' income for their farming business with a P-value of 0.821 which was greater than $\alpha=0.05$. The value of revenue was greater than expenditure indicating that even though the construction of irrigation infrastructure increases farming expenses, farmers still benefit from the results of their rice farming culture.

\subsubsection{Financial analysis of irrigation infrastructure}

Financial analysis of irrigation infrastructure was carried out to see the feasibility of investing in irrigation infrastructure development. The benefit provided from irrigation infrastructure is the addition of agricultural income of farmers due to an increase in the cropping index. Table 1 was used to calculate the flow of benefits and expenditure of irrigation infrastructure investation for 10 years at an average general investment interest rate of $6 \%$ as referred to Bank Indonesia in April 2019 [26] (Table 3).

From the three criteria for assessing financial feasibility, namely IRR, NPV and Net BCR, it is shown that the irrigation infrastructure investment in the research location was very feasible with a fairly fast return on capital at the 3rd year after irrigation infrastructure development. 
Table 3. Criteria for assessing financial feasibility irrigation infrastructure investation at the site.

\begin{tabular}{|c|c|c|c|c|}
\hline No & Feasibility criteria & Feasibility limited & Value & Note \\
\hline 1 & IRR & $>6 \%$ & $>50 \%$ & Feasible \\
\hline 2 & NPV & $>0$ & $802,945,283$ & Feasible \\
\hline 3 & Net BCR & $>1$ & 14 & Feasible \\
\hline 4 & Payback Periode & Fast & 3 year & Very fast return \\
\hline
\end{tabular}

\section{Conclusions}

In general, the application of recommended doze of fertilization with biofertilizers increase rice and straw yields compared to control (PM), altough it is not significantly different compared to farmers' practice with biofertilizer. The income of farmers who utilize irrigation infrastructure was higher than farmer who not use irrigation infrastructure. Improvement of irrigation infrastructure will increase planting area and cropping index of rice which may increase farmers' income.

Acknowledgments. We thank the Indonesian Agency for Agricultural Research and Development for funding this research through the collaboration of research, assessment and development agricultural strategic program (KP4S). We also thank Mr. Asda for helping for crop management and observations in the field. Risqa Nurkhaida, Adang Hamdani, Ahmad Suriadi, and Nani Heryani are main contributors.

\section{References}

1. Indonesian Center for Agricultural Land Resources and Development (ICALRD), Indonesian agricultural land resources: wide, distribution, and potential availability [in Bahasa] (2014)

2. S. Ritung, E. Suryani, D. Subardja, Sukarman, K. Nugroho, Suparto, Hikmatullah, A. Mulyani, C. Tafakresnanto, Y. Sulaeman, R. E. Subandiono, Wahyunto, Ponidi, N. Prasojo, U. Suryana, H. Hidayat, A. Priyono, W. Supriatna, Indonesian agricultural land resources: wide, distribution, and potential availability [in Bahasa] (2015)

3. A. Mulyani, H.S. Mamat, J. Land Res. 13, 1, 41-52 (2019)

4. N. Sutrisno, N. Heryani, J. Land Res. 13, 1, 17-26 (2020)

5. A.R. Darajat, F. Nurrochmad, R. Jayadi, INERSIA. XIII, 2, 154-166 (2017)

6. Irawan, E. Pratiwi, Application of agrimeth biofertilizer to save on fertilizer use and increase farmers' income, in Prosiding Kongres Teknologi Nasional 2016, 25-27 Juli 2016, BPPT, Jakarta (2016)

7. J. Purwani, E. Pratiwi, R.D. Hastuti, S. Salma, I.P. Wardana, Effectiveness of $N, P$, and $K$ fertilization using agrimeth biofertilizer on Inpari 10 variety in inceptisol rice fiels in Bogor, in Seminar Nasional tahun 2017: Support for Rice Technology Innovation to create Indonesia as World's Food Barn Rice Plant Research Center, Sukamandi [in Bahasa] (2018)

8. A. Arafah, J. Agrisystem. 13, 1, 26-30 (2017)

9. D.A. Syavitri, C. Prayogo, S. Gunawan, J. Soil and Land Res. 6, 2, 1341-1352 (2019)

10. A.M. Pasaribu, Agribussines planning and evaluation project (concepts and applications) (Lili Publisher, Yogyakarta, 2012)

11. C.I. Dadimesa, Y.P.K. Suni, S.B. Henong, J. Civ. Eng. Eternitas. 1, 1, 15-22 (2020)

12. A.A. Fisu, J. INA-Rxiv Papers. 1-13 (2019)

13. D.K. Sari, R.A. Sintia, A.R. Hendarsyah, JEPA. 5, 2, 473-483 (2021) 
14. R.D.M. Mangero, M. Yudha, Web-based geographic information system for agricultural land mapping in Bima Regency West Nusa Tenggara, in Nat. Sem. Info. Sys. 2020, 20 Oktober 2020, UNMER, Malang (2011)

15. BPS Kabupaten Bima, Donggo district in numbers (BPS, Bima, 2020)

16. ICALRD, Development of an innovative farming system based on water management (BBSDLP, Bogor, 2019)

17. H. Efendi, M. Ali, R. Misliniyati, J. Inersia. 6, 1, 1-14 (2014)

18. Directorate of Irrigation Management, Technical guidlines for water user farmer associations [in Bahasa] (Directorat General of Agricultural Infrastructure, Ministry of Agriculture, Jakarta, (2010)

19. R. Purba, Study of biological fertilizer application on wet rice crops in Banten, in Prosiding Seminar Nasional Masyarakat Biodiversitas Indonesia, 1 (6), 1524-1527 (2015)

20. R. Saraswati, Peranan pupuk hayati dalam peningkatan produktivitas pangan, Tonggak kemajuan teknologi produksi tanaman pangan: paket dan komponen teknologi produksi padi, in Simp. Penelitian Tanaman Pangan IV, 22-24 November 1999, Bogor, (2000)

21. A. Jamil, Concept and implementation of jarwo super: technology, challenges, and obstacles in work meeting of ICALRD, 25-28 April 2016, Merdeka Hotel, Pati, Central Java (2016)

22. E. Suhartatik, R. Sismiyati, Tonggak Kemajuan Teknologi Produksi Tanaman Pangan, Paket dan Komponen Teknologi Produksi Padi (Pusat Penelitian dan Pengembangan Tanaman Pangan, Bogor, 2000)

23. N.R. Sennang, E. Syam'un, A. Dachlan, J. Agrivigor. 11, 2, 161-170 (2012)

24. M.M. Bakrie, I. Anas, Sugiyanta, K. Idris, J. Soil Env. 12, 2, 25-32 (2010)

25. T. Rustiati, Widyantoro, Response of organic ferltilizer and agrimeth biofertilizer on the growth and yield of upland rice in Indramayu, in Proc. of Indonesian Center for Rice Research, 287-294 [in Bahasa] (2017)

26. Bank Indonesia Pers Release, BI 7-day reverse repo rate, in bi.go.id 25 April 2019 (2019) 